\title{
CHARACTERIZATION OF Vibrio parahaemolyticus ISOLATED FROM OYSTERS AND MUSSELS IN SÃO PAULO, BRAZIL
}

\author{
Martha Virginia Ribeiro ROJAS, Maria Helena MATTÉ, Milena DROPA, Miriam Lopes da SILVA \& Glavur Rogério MATTÉ
}

\begin{abstract}
SUMMARY
Vibrio parahaemolyticus is a marine bacterium, responsible for gastroenteritis in humans. Most of the clinical isolates produce thermostable direct hemolysin (TDH) and TDH-related hemolysin (TRH) encoded by $t d h$ and $t r h$ genes respectively. In this study, twenty-three $V$. parahaemolyticus, previously isolated from oysters and mussels were analyzed by PCR using specific primers for the 16S rRNA and virulence genes ( $t d h$, trh and $t l h)$ and for resistance to different classes of antibiotics and PFGE. Nineteen isolates were confirmed by PCR as V. parahaemolyticus. The $t$ lh gene was present in $100 \%$ of isolates, the $t d h$ gene was identified in two $(10.5 \%)$ isolates, whereas the gene trh was not detected. Each isolate was resistant to at least one of the nine antimicrobials tested. Additionally, all isolates possessed the bla $_{\text {TEM-116 }}$ gene. The presence of this gene in $V$. parahaemolyticus indicates the possibility of spreading this gene in the environment. Atypical strains of $V$. parahaemolyticus were also detected in this study.
\end{abstract}

KEYWORDS: Vibrio parahaemolyticus; $t$ lh, $t$ dh and trh Genes; bla $a_{\mathrm{TEM}-116}$

\section{INTRODUCTION}

Vibrio parahaemolyticus is a human pathogenic Gram-negative halophilic bacterium, a natural inhabitant of the marine environment and can be found in crabs, shrimps, fish, oysters, mussels and other seafoods ${ }^{13,34,41}$. V. parahaemolyticus infections are associated to the ingestion of contaminated raw or undercooked shellfish, especially bivalve molluscs ${ }^{10,13,18}$.

It was first isolated in 1950, during a large outbreak of gastroenteritis that occurred in Japan ${ }^{13}$. Since then this bacterium has been recognized as one of the main agents causing foodborne diseases, in many countries including Asian countries, the United States, France, Mexico, Peru and Chile $^{5,14,15,17,20,22,28,41,45}$. Moreover, V. parahaemolyticus infections have increased globally ${ }^{28,33}$. Studies in Brazil demonstrated the presence of V. parahaemolyticus in environmental samples from a variety of sources as well as in clinical samples $1,25,26,27,31,34,35,38$. In 2002, according to data of the National Health Foundation (FUNASA), in Ceará, Brazil, an outbreak of gastroenteritis occurred, and Kanagawa-positive strains of V. parahaemolyticus serovar O3:K6 were isolated ${ }^{31}$.

The pathogenicity of this bacterium in humans is associated to the production of thermostable direct hemolysin (TDH) and TDH-related hemolysin $(\mathrm{TRH})^{30}$. Many studies have demonstrated that virulent strains of $V$. parahaemolyticus possess either the gene $t d h$ or $t r h$, or both $^{21}$. The evidence of transmission of these genes through plasmids or insertion elements has already been demonstrated. Another thermolabile haemolysin (TLH) which is encoded by $t$ th gene is considered as a species-specific marker. This gene has been detected in all clinical and environmental $V$. parahaemolyticus strains ${ }^{4}$.

Coastal waters and estuarine environments are subjected to waste contamination that could selectively contribute to antimicrobial resistance in bacteria from these environments ${ }^{44}$. Pathogenic strains of $V$. parahaemolyticus have been reported to be resistant to different classes of antimicrobials such as aminoglycosides, beta-lactams and quinolones ${ }^{36,46}$. Thus in this study, antimicrobial susceptibility of V. parahaemolyticus isolated from the environment was evaluated.

V. parahaemolyticus is an important foodborne pathogen, although in São Paulo outbreaks caused by $V$. parahaemolyticus have not been reported by the Center for Epidemiologic Surveillance (CVE). In addition, consumption of raw fish in Brazilian cities is popular ${ }^{39}$. Therefore, in this study, V. parahaemolyticus isolated from shellfish were characterized by PCR targeted to $16 \mathrm{~S}$ rRNA and virulence genes, antibiotic resistance patterns and DNA profiles by PFGE.

\section{MATERIAL AND METHODS}

Strains. Twenty-three V. parahaemolyticus strains isolated from oysters and mussels, collected from aquatic environments, fish markets and restaurants in São Paulo, Brazil, between February 1989 and January 1990, were used in this study. Isolates were kept in Luria Bertani broth containing $60 \%$ glycerol at $-80{ }^{\circ} \mathrm{C}$, in the Public Health Laboratory

Public Health Laboratory, School of Public Health/University of São Paulo. Av. Dr. Arnaldo 715, 01246-904 São Paulo, SP, Brazil.

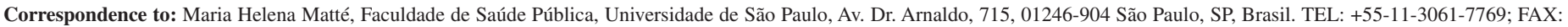
+55-11-3083-3501. E-mail: mhmatte@usp.br 
ROJAS, M.V.R.; MATTÉ, M.H.; DROPA, M.; SILVA, M.L. \& MATTÉ, G.R. - Characterization of Vibrio parahaemolyticus isolated from oysters and mussels in São Paulo, Brazil. Rev. Inst. Med. Trop. Sao Paulo, 53(4): 201-5, 2011.

Culture Collection, School of Public Health/University of São Paulo. The isolates were identified as $V$. parahaemolyticus by standard biochemical methods as described previously ${ }^{26}$. To determine the viability, the strains were cultured in thiosulphate citrate bile salts sucrose (TCBS) agar (Difco, France) at $35^{\circ} \mathrm{C}$ for 24 hours and screened in Triple Sugar Iron (TSI) agar (Merck, USA) and citochrome oxidase production. A V. parahaemolyticus positive control was kindly provided by Fundação Instituto Oswaldo Cruz (FIOCRUZ - Rio de Janeiro, Brazil). V. harveyi was used as a negative control. DNA extraction was carried out for all samples using the heat-shock technique ${ }^{7}$.

Kanagawa Test. Wagatsuma agar containing 5\% human erythrocytes was used to screen all $V$. parahaemolyticus strains for $\beta$-hemolysis by incubation at $35^{\circ} \mathrm{C}$ for 24 hours ${ }^{43}$.

Antimicrobial Susceptibility Test. Antimicrobial susceptibility test was performed using disc-diffusion, Kirby-Bauer method ${ }^{29}$. The antibiotics used were streptomycin $(10 \mu \mathrm{g})$, gentamicin $(10 \mu \mathrm{g})$, chloramphenicol $(30 \mu \mathrm{g})$, nalidixic acid $(30 \mu \mathrm{g})$, ciprofloxacin $(5 \mu \mathrm{g})$, cotrimoxazole $(25 \mu \mathrm{g})$, tetracycline $(30 \mu \mathrm{g})$, ampicillin $(10 \mu \mathrm{g})$, cefotaxime $(30 \mu \mathrm{g})$, ceftazidime $(30 \mu \mathrm{g})$, cefpodoxime $(10 \mu \mathrm{g})$ and imipenem $(10 \mu \mathrm{g})\left(\mathrm{OXOID}{ }^{\circledR}\right.$, England $)$.

Polymerase Chain Reaction (PCR). PCR was performed to identify $V$. parahaemolyticus using 16S rRNA as a targeted gene. Multiplex PCR was established for detection of virulence genes $t d h, t r h$ and $t h$. In the present study, the majority of $V$. parahaemolyticus strains were resistant to ampicilin. In addition, bla $a_{\mathrm{TEM}}$ genes have recently been detected in many Brazilian environmental bacteria ${ }^{2}$. Therefore, we also investigated the presence of bla $a_{\text {TEM }}$ genes in V. parahaemolyticus strains by PCR. All primers used are indicated in Table 1.

Pulsed Field Gel Electrophoresis (PFGE). PFGE technique was performed as previously described ${ }^{40}$. Briefly, DNA was digested with $40 \mathrm{U}$ of SfiI restriction enzyme (GE Healthcare, UK). Restriction fragments were separated by pulsed field gel electrophoresis in a Chef Mapper apparatus
(Bio-Rad Laboratories, Hercules, CA) in a two-step procedure as follows: Block 1: $6 \mathrm{~V} / \mathrm{cm}, 14^{\circ} \mathrm{C}$, for $13 \mathrm{~h}$, pulse ramp of $2 \mathrm{~s}$ to $10 \mathrm{~s}, 120^{\circ}$ angle. Block 2: $6 \mathrm{~V} / \mathrm{cm}, 14^{\circ} \mathrm{C}$, for six hours, pulse ramp of $20 \mathrm{~s}$ to $25 \mathrm{~s}, 120^{\circ}$ angle. Gels were stained with ethidium bromide. DNA profiles obtained by PFGE were visualized in an Epi Chemi II Darkroom (UVP Bioimaging Systems). PFGE profiles were analyzed using Gel Works 1D Advanced 4.01 and Gel Works 1D Database 1.12 (UVP Bioimaging Systems, Upland, CA).

\section{RESULTS}

Identification of $\boldsymbol{V}$. parahaemolyticus. Twenty-three strains presumptively identified as $V$. parahaemolyticus were submitted to biochemical and molecular tests. Four strains (17.4\%) were negative for PCR targeted to $16 \mathrm{~S}$ rRNA. Nineteen strains (82.6\%) including five strains with atypical biochemical tests were confirmed as $V$. parahaemolyticus by PCR. The presence of $t$ th gene was observed in all 19 V. parahaemolyticus strains. Biochemical tests revealed atypical characteristics in two $(8.7 \%)$ strains which were sucrose positive. Three strains (13.0\%), were negative for ethanol as sole carbon source. Figure 1 summarizes the results of biochemical tests, presence of virulence genes, Kanagawa phenomenon, antimicrobial susceptibility and PFGE profiles of $V$. parahaemolyticus strains evaluated in this study.

Virulence. The $\beta$-hemolysis in Wagatsuma agar (Kanagawa phenomenon) was observed in three strains of $V$. parahaemolyticus $(15.8 \%)$. The presence of virulence gene $t d h$ was observed in two $(10.5 \%)$, but none of the strains were positive for $t r h$ gene.

Antibiotics resistance. From 19 strains tested, six were resistant to at least two antimicrobial agents (Fig. 1). All strains were susceptible to imipenem, nalidixic acid and ceftazidime. It is important to highlight that all strains had intermediate results for streptomycin. For bla $\mathrm{TEM}_{\mathrm{TEM}}$ genes evaluation, all $V$. parahaemolyticus isolates presented the expected $972 \mathrm{pb}$ fragment, and sequencing of these amplicons demonstrated $100 \%$ similarity to $b l a_{\text {TEM-116 }}$ (GenBank accession numbers of JF327790 to JF327797 ).

Table 1

Sequences of primers used to confirm the taxonomic position, detect virulence genes and detect $b l a_{\text {TEM }}$ genes

\begin{tabular}{|c|c|c|c|c|}
\hline $\begin{array}{l}\text { Gene } \\
\text { target }\end{array}$ & Primer sequence & $\begin{array}{l}\text { Band size } \\
\text { (bp) }\end{array}$ & PCR cycle* & Reference \\
\hline tlh & $\begin{array}{ll}\mathrm{L}-t t: & \text { (5'-AAAGCGGATTATGCAGAAGCACTG-3') } \\
\mathrm{R}-t t: & \text { (5'-GCTACTTTCTAGCATTTTCTCTGC-3') } \\
\end{array}$ & 450 & \multirow{3}{*}{$\begin{array}{c}30 \text { cycles: } \\
94^{\circ} \mathrm{C}-1 \mathrm{~min} . \\
58^{\circ} \mathrm{C}-1 \mathrm{~min} . \\
72^{\circ} \mathrm{C}-1 \mathrm{~min}\end{array}$} & \multirow{3}{*}{4} \\
\hline$t d h$ & $\begin{array}{l}\text { L-tdh: (5'-GTAAAGGTCTCTGACTTTTGGAC-3') } \\
\text { R- } t d h:\left(5^{\prime}-T G G A A T A G A A C C T T C A T C T T C A C C-3 '\right)\end{array}$ & 269 & & \\
\hline $\operatorname{trh}$ & $\begin{array}{l}\text { L-trh: (5'-TTGGCTTCGATATTTTCAGTATCT-3') } \\
\text { R-trh: (5'-CATAACAAACATATGCCCATTTCCG-3') }\end{array}$ & 500 & & \\
\hline 16S rRNA & $\begin{array}{l}\text { VparaF (5'-GCTGACAAAACAACAATTTATTGTT-3') } \\
\text { VparaR (5'-GGAGTTTCGAGTTGATGAAC-3') }\end{array}$ & 170 & $\begin{array}{c}35 \text { cycles: } \\
94^{\circ} \mathrm{C}-1 \mathrm{~min} . \\
55^{\circ} \mathrm{C}-1 \mathrm{~min} . \\
72{ }^{\circ} \mathrm{C}-1 \mathrm{~min}\end{array}$ & 19 \\
\hline$b l a_{\mathrm{TEM}}$ & $\begin{array}{l}\text { TEM CR F (5'-CGWGTCGCCCTTATTCCCT-3') } \\
\text { TEM R } \quad\left(5^{\prime} \text { 'CCAAWGCTTAATCAGTGAG-3') }\right.\end{array}$ & 840 & $\begin{array}{c}30 \text { cycles: } \\
94{ }^{\circ} \mathrm{C}-45 \mathrm{~s} \\
52{ }^{\circ} \mathrm{C}-1 \mathrm{~min} . \\
72{ }^{\circ} \mathrm{C}-1 \mathrm{~min}\end{array}$ & 6 \\
\hline
\end{tabular}

\footnotetext{
*All amplifications had one initial cycle of $94{ }^{\circ} \mathrm{C}$ for $5 \mathrm{~min}$., final extension of $72{ }^{\circ} \mathrm{C}$ for $10 \mathrm{~min}$. and were maintained at $4{ }^{\circ} \mathrm{C}$ after PCR.
} 


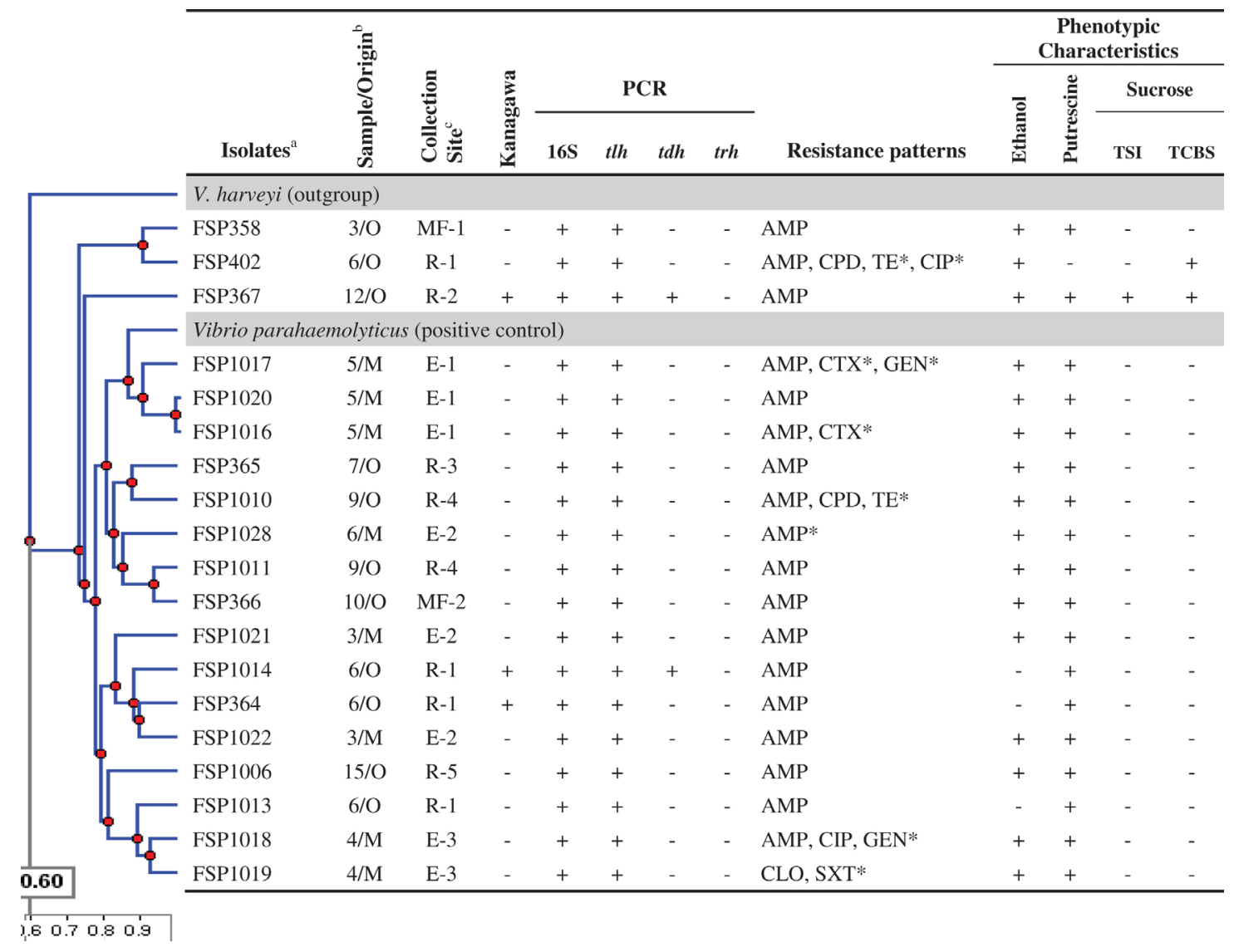

${ }^{a}$ FSP, Faculdade de Saúde Pública; ' $\mathrm{O}$, oysters; M, mussels; ${ }^{\mathrm{c}} \mathrm{MF}$, market fish; R, restaurant; E, environment; PCR, polymerase chain reaction; $16 \mathrm{~S}$, 16S rRNA gene sequence; $t h$, thermolabile haemolysin gene; $t d h$, thermostable direct haemolysin gene; $t r h$, thermostable-related haemolysin gene; TSI, triple-sugar-iron agar; TCBS, thiosulphate-citrate-bile salts-sucrose agar; AMP, ampicillim; CTX, cefotaxime; CPD, cefpodoxime; CLO, chloramphenicol; CIP, ciprofloxacin; GEN, gentamicin; TE, tetracycline; SXT, cotrimoxazole; *Isolate exhibiting intermediate resistance against indicated antibiotic; + , positive; - , negative.

Fig. 1 - Phenotypic and genotypic characteristics of V. parahaemolyticus according to Pulsed Field Gel Electrophoresis profile.

PFGE. The PFGE analysis demonstrated heterogeneity among the V. parahaemolyticus isolates except for isolates FSP1020 and FSP1016 that were very close related, with only one band difference suggesting that they might have originated from the same clone. However, these strains showed differences in antimicrobial susceptibility. Overall, the graphic representation of the Dice's similarity coefficient matrix showed similarity above $80 \%$ (Fig. 1).

\section{DISCUSSION}

Four strains with typical biochemical reactions were negative for PCR identification of V. parahaemolyticus. On the other hand, FSP367, FSP402, FSP364, FSP1013 and FSP1014, which were strains with atypical phenotypic characteristics (positive reaction for sucrose and negative for ethanol as sole carbon source) were confirmed as Vibrio parahaemolyticus by PCR. It has been demonstrated that phenotypic tests are often unable to discriminate species of vibrios ${ }^{9}$. In this study, $t$ lh gene was a useful marker for confirmation of V. parahaemolyticus and the results of detection of this gene corroborates the results obtained for 16S rRNA gene ${ }^{12}$. Therefore, molecular techniques are a useful tool for identification of environmental V. parahaemolyticus strains if atypical V. parahaemolyticus is detected ${ }^{13,18,42}$.

In regard to the presence of virulence genes in V. parahaemolyticus, $t d h$ was observed in two $(10.5 \%)$ strains which corroborates the results of other authors that this gene was absent in the majority of environmental strains of $V$. parahaemolyticus ${ }^{3,30}$. The trh gene was not detected in any tested strains. In the present study it was observed that one strain showed beta-hemolysis on Wagatsuma agar (Kanagawa positive) but it was negative for $t d h$ gene. This phenomenon has been reported in Brazil $1^{1,4,16,24,32}$ and might be due to deletion or mutation in the $t d h$ gene $^{33}$.

PFGE has been used to investigate diversity of V. parahaemolyticus and has been applied to characterize bacterial strains from environment and foodborne outbreaks ${ }^{37,45}$. In the present study, genotypic diversity of V. parahaemolyticus strains was achieved by PFGE using SfiI. This methodology is widely used in epidemiological studies for many genus of bacteria ${ }^{8}$ and this is the first application to access the diversity of $V$. parahaemolyticus strains isolated from Brazilian samples. These 
ROJAS, M.V.R.; MATTÉ, M.H.; DROPA, M.; SILVA, M.L. \& MATTÉ, G.R. - Characterization of Vibrio parahaemolyticus isolated from oysters and mussels in São Paulo, Brazil. Rev. Inst. Med. Trop. Sao Paulo, 53(4): 201-5, 2011.

results may be kept as a database of environmental strains to be used in investigations in case of outbreaks.

In the present study it was demonstrated that environmental isolates showed low susceptibility to penicillins and aminoglycosides, thus, they may have a low effectiveness in clinical treatment of V. parahaemolyticus.

It has been demonstrated that clinical isolates of $V$. parahaemolyticus show intermediate susceptibility to gentamicin, resistance to streptomycin and ampicillin, and susceptibility to trimethoprim-sulphamethoxazole ${ }^{23}$. In addition, clinical and environmental V. parahaemolyticus strains also show resistance to chloramphenicol, tetracycline and cefotaxime ${ }^{46}$. Results obtained in this study, demonstrated the same resistance profile to streptomycin and ampicillin that was observed in clinical strains, but most of our $V$. parahaemolyticus environmental isolates were susceptible to chloramphenicol, tetracycline and cefotaxime. Resistance to cotrimoxazole (combination of trimethoprim and sulfamethoxazole) and chloramphenicol was detected in FSP1019 strain.

The acquisition of resistance genes can occur by mobile elements such as plasmids and integrons, which have already been described in $V$. parahaemolyticus and other Vibrio species ${ }^{42}$.

In the present study, bla $a_{\text {TEM }}$ genes were detected in all tested $V$. parahaemolyticus and sequencing of this gene revealed $100 \%$ similarity with bla $a_{\text {TEM-116. }}$. The presence of this gene in V. parahaemolyticus isolates from several sites in São Paulo State indicates that $b l a_{\text {TEM-116 }}$ genes have been disseminated in the marine environment. In fact, studies demonstrated the presence of this gene in Aeromonas spp. and Klebsiella pneumoniae isolated from environment and clinical samples in the same regions in São Paulo ${ }^{2,11}$.

To contribute to a better characterization of the pathogen, further studies on V. parahaemolyticus from its natural environment, seafood or clinical samples are essential. Thus, the molecular methods used in this study may be useful in the monitoring of this microorganism. However, in order for this application to be viable, it is necessary to improve the clinical diagnosis for V. parahaemolyticus infections. Therefore, it is recommended that routine searching for halophilic vibrios and a systematic notification of clinical cases be undertaken in hospital areas located near coastal regions and in places where consumption of seafood is a regular practice in order to identify the prevalence of vibriosis in the population. Consequently, health professionals should be directed, in cases of gastroenteritis associated with seafood consumption, to request specific culture for the isolation and characterization of vibrios, including V.parahaemolyticus. Such measures could provide relevant information to Health Surveillance services.

\section{RESUMO}

\section{Caracterização de Vibrio parahaemolyticus isolados de ostras e mexilhões em São Paulo, Brasil}

Vibrio parahaemolyticus é uma bactéria marinha, responsável por gastroenterite em humanos. A maioria dos isolados clínicos produzem hemolisina termoestável direta (TDH) e hemolisina TDH-relacionada (TRH) codificadas por genes $t d h$ e $t r h$, respectivamente. Neste estudo, vinte e três $V$. parahaemolyticus, previamente isolados de ostras e mexilhões foram analisados por PCR utilizando indicadores específicos para o gene $16 \mathrm{~S}$ rRNA, genes de virulência ( $t d h$, $t r h$ e $t l h)$, resistência a diferentes classes de antibióticos, e PFGE. Dezenove isolados foram confirmados por PCR, como $V$. parahaemolyticus. O gene th estava presente em $100 \%$ dos isolados, o gene $t d h$ foi identificado em dois $(10,5 \%)$ dos isolados, enquanto que o gene trh não foi detectado. Cada isolado foi resistente a pelo menos um dos nove antibióticos testados. Além disso, todos os isolados apresentaram resultado positivo para o

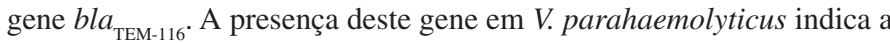
possibilidade de propagação desse gene no ambiente. Cepas atípicas de V. parahaemolyticus foram também detectadas neste estudo.

\section{ACKNOWLEDGEMENTS}

Centro Colaborador em Vigilância Sanitária/FSP-CECOVISA/USPCA no. 06/99-44-ANVSMS, Process \# 2001.1.1048.6.9, for support as part of a technology transfer project.

\section{REFERENCES}

1. Archer RM, Moretto E. Ocorrência de Vibrio parahaemolyticus em mexilhões (Perna perna, Linnaeus, 1758) de banco natural do litoral do município de Palhoça, Santa Catarina, Brasil. Cad Saude Publica. 1994;10:379-86.

2. Balsalobre LC, Dropa M, Oliveira DE, Lincopan N, Mamizuka EM, Matté GR, et al. Presence of bla $a_{\mathrm{TEM}-116}$ gene in environmental isolates of Aeromonas hydrophila and Aeromonas jandaei from Brazil. Braz J Microbiol. 2010;41:718-9.

3. Bates TC, Oliver JD. The viable but nonculturable state of Kanagawa positive and negative strains of Vibrio parahaemolyticus. J Microbiol. 2004;42:74-9.

4. Bej AK, Patterson DP, Brasher CW, Vickery MCL, Jones DD, Kaysner CA. Detection of total and hemolysin-producing Vibrio parahaemolyticus in shellfish using multiplex PCR amplification of $t h$, $t d h$ and $t r h$. J. Microbiol Methods. 1999;36:215-25.

5. Cabanillas-Beltrán H, LLausás-Magaña E, Romero R, Espinoza A, García-Gasca A, Nishibuchi M, et al. Outbreak of gastroenteritis caused by the pandemic Vibrio parahaemolyticus O3:K6 in Mexico. FEMS Microbiol Lett. 2006;265:76-80.

6. Cao V, Lambert T, Nhu DQ, Loan HK, Hoang NK, Arlet G, et al. Distribution of extended-spectrum $\beta$-lactamases in clinical isolates of Enterobacteriaceae in Vietnam. Antimicrob Agents Chemoter. 2002;46:3739-43.

7. Chapman PA, Ellin M, Ashton R, Shafique W. Comparison of culture, PCR and immunoassays for detecting Escherichia coli $\mathrm{O} 157$ following enrichment culture and immunomagnetic separation performed on naturally contaminated raw meat products. Int J Food Microbiol. 2001;68:11-20.

8. Chiu TH, Duan J, Su YC. Characteristics of virulent Vibrio parahaemolyticus isolated from Oregon and Washington. J Food Prot. 2007;70:1011-6.

9. Croci L, Suffredini E, Cozzi L, Toti L, Ottaviani D, Pruzzo C, et al. Comparison of different biochemical and molecular methods for the identification of Vibrio parahaemolyticus. J Appl Microbiol. 2007;102:229-37.

10. Daniels NA, Ray B, Easton A, Marano N, Kahn E, McShan AL $2^{\text {nd }}$, et al. Emergence of a new Vibrio parahaemolyticus serotype in raw oysters: a prevention quandary. JAMA. 2000;284:1541-5.

11. Dropa M, Balsalobre LC, Lincopan N, Mamizuka EM, Cassettari VC, Matté GR, et al. Emergence of Klebsiella pneumoniae carrying the novel extended-spectrum $\beta$-lactamase gene variants $b l a_{\mathrm{SHV}-40}, b l a_{\mathrm{TEM}-116}$ and the class 1 integron-associated bla $_{\text {GES-7 }}$ in Brazil. Clin Microbiol Infect. 2010;16:630-2.

12. Fabbro C, Cataletto B, Del Negro P. Detection of pathogenic Vibrio parahaemolyticus through biochemical and molecular-based methodologies in coastal waters of the Gulf of Trieste (North Adriatic Sea). FEMS Microbiol Lett. 2010;307:158-64. 

Med. Trop. Sao Paulo, 53(4): 201-5, 2011.

13. Farmer III JJ, Janda M, Brenner FW, Cameron DN, Birkhead KM. Genus I. Vibrio Pacini 1854, 411AL. In: Brenner DJ, Krieg NR, Staley JT, editors. Bergey's manual of systematic Bacteriology. The Proteobacteria. Part B. The Gammaproteobacteria. $2^{\text {nd }}$ ed. New York: Springer; 2005. v. 2, p. 494-546.

14. Gil AI, Miranda H, Lanata CF, Prada A, Hall ER, Barreno CM, et al. O3:K6 serotype of Vibrio parahaemolyticus identical to the global pandemic clone associated with diarrhea in Peru. Int J Infect Dis. 2007;11:324-8.

15. González-Escalona N, Cachicas V, Acevedo C, Rioseco ML, Vergara JA, Cabello F, et al. Vibrio parahaemolyticus diarrhea, Chile, 1998 and 2004. Emerg Infect Dis. 2005; 11:129-31.

16. Honda T, Ni YX, Hata A, Yoh M, Miwatani T, Okamoto T, et al. Properties of a hemolysin related to the thermostable direct hemolysin produced by a Kanagawa phenomenon negative, clinical isolate of Vibrio parahaemolyticus. Can J Microbiol. 1990;36:395-9.

17. Infectious Disease Surveillance Center. Bacterial food poisoning in Japan, 1998-2007. Infect Agents Surveill Rep. 2008; 29(8): 213-5. Available from: http://idsc.nih.go.jp/ iasr/29/341/tpc342.html

18. Joseph SW, Colwell RR, Kaper JB. Vibrio parahaemolyticus and related halophilic vibrios. Crit Rev Microbiol. 1982;10:77-124.

19. Kong RYC, Lee SKY, Law TWF, Law SHW, Wu RSS. Rapid detection of six types of bacterial pathogens in marine waters by multiplex PCR. Water Research. 2002;36:2802-12.

20. Lam T, Wong C. Review of notifiable diseases in 2008. Public Health Epidemiol Bull. 2009;18(2):31-42

21. Lee C, Pan SF. Rapid and specific detection of the thermostable direct haemolysin gene in Vibrio parahaemolyticus by the polymerase chain reaction. J Gen Microbiol. 1993;139:3225-31.

22. Lemoine $\mathrm{T}$, Germanetto $\mathrm{P}$, Giraud $\mathrm{P}$. Toxi-infection alimentaire collective à Vibrio parahaemolyticus. Bull Épidémiol Hebd. 1999;10:37-8.

23. Lozano-León A, Torres J, Osorio CR, Martínez-Urtaza J. Identification of tdh-positive Vibrio parahaemolyticus from an outbreak associated with raw oyster consumption in Spain. FEMS Microbiol Lett. 2003;226:281-4.

24. Magalhães M, Magalhães V, Antas MG, Tateno S. Isolation of urease-positive Vibrio parahaemolyticus from diarrheal patients in Northeast Brazil. Rev Inst Med Trop Sao Paulo. 1991;33:263-5.

25. Magalhães M, Takeda Y, Magalhães V, Tateno S. Brazilian urease-positive strains of Vibrio parahaemolyticus carry genetic potential to produce the TDH-related hemolysin. Mem Inst Oswaldo Cruz. 1992;87:167-8.

26. Matté GR, Matté MH, Sato MIZ, Sanchez PS, Rivera IG, Martins MT. Potentially pathogenic vibrios associated with mussels from a tropical region on the Atlantic coast of Brazil. J Appl Bacteriol. 1994;77:281-7.

27. Matté MH, Baldassi L, Barbosa ML, Malucelli MIC, Nitrini SMOO, Matté GR Virulence factors of Vibrio metschinikovii strains isolated from fish in Brazil. Food Control. 2007;18:747-51.

28. Nair GB, Ramamurthy T, Bhattacharya SK, Dutta B, Takeda Y, Sack DA. Global dissemination of Vibrio parahaemolyticus serotype O3:K6 and its serovariants. Clin Microbiol Rev. 2007;20:39-48.

29. National Committee for Clinical Laboratory Standards. Performance standards for antimicrobial disk susceptibility tests for bacteria that grow aerobically. $8^{\text {th }}$ ed. Wayne: NCCLS; 2003. (Approved Standard. NCCLS document M2-A8).

30. Nishibuchi M, Kaper JB. Thermostable direct hemolysin gene of Vibrio parahaemolyticus: a virulence gene acquired by a marine bacterium. Infect Immun. 1995;63:2093-9.
31. Oliveira WK, Wada MY, Lima JRC, Pinheiro AMC, Britto NPB, Arcanjo SRS, et al. Investigação do surto de gastroenterite por Vibrio parahaemolyticus em Fortaleza/ Ceará, Setembro, 2002. Bol Eletrôn Epidemiol. 2002;4:5-7.

32. Ottaviani D, Santarelli S, Bacchiocchi S, Masini L, Ghittino C, Bacchiocchi I. Presence of pathogenic Vibrio parahaemolyticus strains in mussels from the Adriatic Sea, Italy. Food Microbiol. 2005;22:585-90

33. Park KS, Ono T, Rokuda M, Jang MH, Iida T, Honda T. Cytotoxicity and enterotoxicity of the thermostable direct hemolysin-deletion mutants of Vibrio parahaemolyticus. Microbiol Immunol. 2004;48:313-8.

34. Pereira CS, Viana CM, Rodrigues DP. Vibrio parahaemolyticus produtores de urease isolados a partir de ostras (Crassostrea rizophorae) coletadas in natura em restaurante e mexilhões (Perna perna) de banco natural. Ciênc Tecnol Aliment. 2004;24:591-5.

35. Pereira CS, Possas CA, Viana CM, Rodrigues DP. Características de Vibrio parahaemolyticus isolados de mexilhões (Perna perna) comercializados em Niterói, Rio de Janeiro. Rev Soc Bras Med Trop. 2007;40:56-9.

36. Poirel L, Liard A, Rodriguez-Martinez JM, Nordmann P. Vibrionaceae as a possible source of Qnr-like quinolone resistance determinants. J Antimicrob Chemother. 2005;56:1118-21.

37. Rahman M, Bhuiyan NA, Kuhn I, Ramamurthy T, Rahman M, Mollby R, et al. Biochemical fingerprinting of Vibrio parahaemolyticus by the PhenePlate system: comparison between pandemic and non-pandemic serotypes. Epidemiol Infect. 2006;134:985-9.

38. Serra CLM, Cavalcante PRS, Alves LMC, Nascimento AR, Diniz SCCS. Avaliação de parâmetros físicos e químicos e pesquisa de Vibrio parahaemolyticus em águas do estuário do rio Anil (São Luís, Estado do Maranhão). Acta Scientiarium Biol Sci. 2003;25:261-3.

39. Silva ML, Matté GR, Germano PML, Matté MH. Occurrence of pathogenic microorganisms in fish sold in São Paulo, Brazil. J Food Saf. 2010;30:94-110.

40. Singh DV, Matté MH, Matté GR, Jiang S, Sabeena F, Shukla BN, et al. Molecular analysis of Vibrio cholerae O1, O139, non-O1, and non-O139 strains: clonal relationships between clinical and environmental isolates. Appl Environ Microbiol. 2001;67:910-21

41. Su YC, Liu C. Vibrio parahaemolyticus: a concern of seafood safety. Food Microbiol 2007; $24: 549-58$

42. Thompson FL, Iida T, Swings J. Biodiversity of vibrios. Microbiol Mol Biol Rev. 2004;68:403-31

43. Wagatsuma S. A medium for the test of the haemolytic activity of Vibrio parahaemolyticus. Media Circle. 1968;13:159-61.

44. Wang Y, Leung PC, Qian PY, Gu JD. Antibiotic resistance and plasmid profile of environmental isolates of Vibrio species from Mai Po Nature Reserve, Hong Kong. Ecotoxicology. 2006;15:371-8

45. Wong HC, Liu SH, Chiou CS, Nishibuchi M, Lee BK, Suthienkul O, et al. A pulsedfield gel electrophoresis typing scheme for Vibrio parahaemolyticus isolates from fifteen countries. Int J Food Microbiol. 2007;114:280-7.

46. Zanetti S, Spanu T, Deriu A, Romano L, Sechi LA, Fadda G. In vitro susceptibility of Vibrio spp. isolated from the environment. Int J Antimicrob Agents. 2001;17:407-9.

Received: 3 December 2010

Accepted: 20 June 2011 